\title{
Detection of 16S r RNA gene of Helicobacter pylori in patients with peptic ulcer and gastric carcinoma: molecular and bacteriological study
}

\author{
Mohamed B. AL-Jobori ${ }^{1}$, Mushtak T. AL-Ouqailii ${ }^{2}$ and Essam M. Abdullah ${ }^{3}$ \\ 1-College of Medicine. University of Al-Anbar, Iraq \\ 2-College of Pharmacy. University of Al-Anbar, Iraq \\ 3-Department of Microbiology University of Al-Anbar, Iraq.
}

\begin{abstract}
Objective and background: It is well document Helicobacter pylori, has been a major causes of peptic ulcer, gastric ulcer, duodenal ulcer disease and is an early risk factor for gastric carcinoma. This study has been undertaken forisolation of Helicobacter pylori form clinical specimens using culture technique and detection the role of this technique in the investigation of $H$. pylori infection. Also detection of anti $-H$. pylori IgG using enzyme linked immune sorbent assay (ELISA), further molecular detection of $H$. pylori genome by amplification of $16 \mathrm{~s}$ r-ribonucleic acid gene with $520 \mathrm{pb}$ by polymerase chain reaction PCR.

Patients and Methods: Atotal of Eighty five adult patient attending the gastro endoscopy unit of Al- Ramadi Teaching Hospital to undergo selective esophageal gastroduodenoscopy (OGD) were studied. They were all suffering from clinical manifestation of duodenal ulcer (DU), gastric ulcer (GU), peptic ulcer (PU) and nonulcer dyspepsia (NUD). Culture and ELISA technique were used. Further molecular detect of $16 \mathrm{~s} r$ RNA gene was performed by PCR.
\end{abstract}

Results: A total 7(8.23\%) with GU, 5 (5.91\%) with PU, 10 (11.75\%) with DU and 28 (32.94\%) patients with NUD were positive by urease test (UT). A total $3(3.52 \%)$ patients with GU, $4(4.71 \%)$ patients with PU and $3(3.52 \%)$ patients with DU were positive by culture while no one of the patients of NUD was positive by culture. By using ELISA technique $18(21.2 \%)$ patients were positive by ELISA. In the present study, the presence of Helicobacter DNA was investigated using a Helicobacter species-specific 16srRNA PCR amplification.DNA extracted from human blood and bacterial colonies. PCR showed $20(100 \%)$ of cases positive result from human blood while $6(60 \%)$ of cases were positive result of PCR from bacterial colonies.

Conclusions: The study concludedthat urease test was useful as preliminary screening test and important in give indicate for $H$. pylori presence. Further, the role of culture was very important in the detection of $H$. pylori in clinical samples. Furthermore, the immunologically bases serological test, detection of anti- $H$ pyloriIgG by ELISA technique was undependable serological test. It can be used as preliminary screening test for detection of $H$. pylori in association with the other tests. FurtherPCR was sensitive and specific test for diagnosis of $H$. pyloriinfection.

Keywords: H. pylori, Gastrc ulcer, peptic ulcer, duodenal ulcer, culture, ELISA, PCR.

INTRODUCTION

Helicobacter pylori are a Gramnegative, motile bacterium that has been implicated in the etiology of most gastritis, duodenal ulcers and is associated with lymphoproliferative disorders as well as gastric carcinoma. $H$. pylori fastidious bacterium that resides on the human gastric epithelium. It grows under microaerophilic environment. Subsequent to the first isolation of $H$. pylori in 1982, Marshall, B.J. and Warren, JR. (1984), its association with gastritis, peptic ulcer (PU) and gastric 
cancer (GC) and mucosa associated lymphoid tissue (MALT) lymphoma in human Ashok, Kumar and Imran, Khan (2010). Although H. pylori infection is widespread throughout the world Graham, D Y. (1991). The route of Helicobacter pylori transmission from person-to-person transfer by fecal-oral and oral-oral mode Luigina Cellini1, et al., (2010). The diagnosis of $H$. pylori infection is an important issue. Recently, there are at least seven diagnostic assays for $H$. pylori: bacterial culture, urease test, urea breath test, histology, PCR, serology, and a stool antigen test culture, urease test, urea breath test, histology, and the stool antigen test are limited when few organisms are present or when patients are taking acid suppressing agents (proton pump inhibitors) Ho, SA. et al., (1991). Culture and identifying $H$. pylori in gastric biopsy require experienceand dexterity, as identification and culturing are sometimes difficult. Moreover, the erratic distribution of $H$. pylori could also lead to defective results. Microscopy and UT can be high lyspecific if strictly performed, but they are based on biopsy specimens and thus are theoretically may be due to improper specimen collection as in the case of culture Yoshida, H. et al., (1998). Since invasive methods are expensive, less non invasive methods such as serological examination of blood and the urea breath test (UBT) have become more popular Zagari, RM. et al.,

(1999). However, positive results by blood serology do not necessarily allow delineation of active $H$. pyloriinfection, Luigina Cellini1, (2010). Serology may not differentiate active from past infection and cannot be used to indicate theclearance of $H$. pylori from the stomach because antibodies may stay at the same level even after eradication of the bacteria Ashok Kumar and Imran Khan., (2010). Like these techniques, PCR also has drawbacks.
Molecular methods like polymerase chain reaction (PCR) have the potential to accurately determine both the presence of infection and the genotype of bacteria, and have marked sensitivity and specificity Gramley, WA. et al., (1999). These techniques have been used successfully to detect $H$. pylori DNA in human blood and bacterial colonies by amplifying16s rRNA gene. The16s r RNA is one of the specific targets to confirm $H$. pylori infection, and positive amplification of $H$. pylori specific DNA may be considered as a direct evidence of the presence of the pathogen Yoshida H. et al., (1998); Chong SK, et al., (1996) and Hoshina S. et al., (1990).

\section{Patients and Methods:}

Atotal of Eighty five adult patient attending the gastro endoscopy unit of Al-Ramadi Teaching Hospital to undergo selective esophageal gastroduodenoscopy (OGD) from December 2010 to April 2011 were eligible for this study. They were all suffering from clinical manifestation of gastro duodenal ulcer (DU), gastric ulcer (GU), peptic ulcer (PU) andnon-ulcer dyspepsia (NUD). Patients were divided broadly into 4 categories:

Group 1 - Patients with gastric ulcer (G.U.)

Group 2 - Patients with peptic ulcer (P.U.)

Group 3- Patients with duodenal ulcer (D.U.)

Group 4- Patients with non-ulcer dyspepsia (NUD)

The ethics committee of the institute granted approval for the study and the consents were obtained from all the patients. Patients of all three groups who had received antimicrobial therapy, $\mathrm{H} 2$ receptor blockers, proton pump inhibitors and non-steroidal antiinflammatory drugs in the last 4 weeks before endoscopy were excluded from the study. During eachendoscopic examination, 3antral biopsies were 
obtained; eachbiopsy was used for isolation and identification of $H$. pylori by different methods.

\section{Isolation and Identification of $\boldsymbol{H}$.} pylori:

Urease test (UT):

One piece of antral biopsy was inoculated in urease agar tube. The presence of urease was indicated by color change from yellow to pink, Aydin F. et al., (2004).

\section{Microscopy:}

Smears were prepared from the biopsy tissue by crushing it between the slides. Crushed smear was air dried, heat fixed and stained by modified Gram method. This technique rapid and sensitive for $80 \%$.

\section{Culture:}

Antral biopsies from all patients were collected from pre pyloric area and transported to the laboratory in $2 \mathrm{ml}$ of Brain heart infusion broth. Before culture make section to biopsy by sterile needles to release $H$. pylori from biopsy internal. Biopsies were cultured within an hour of collection on Brucella agar (Difco, USA) supplemented with $7.5 \%$ horse blood, chocolate Morgan, C. et al., (2003), and vancomycin $5 \mathrm{mg}$, polymyxin B 2500 units and amphotericinB3mg per liter. The plates were incubated at $37^{\circ} \mathrm{C}$ under microaerophilic conditions provided by a candle jar technique.

Escherichia coli growth was used to maintainmicroaerobic conditions and asterile cotton wool soaked in sterile Distilled Water was also put to provide the high humidity. Plateswere examined after 48 hours, there after 72 hours for 7 days. Morgan, C. et al., (2003) and Ashok Kumar and Imran Khan. (2010). Immunological test:

All study specimens were submitted to ELISA technology for detection of $H$. pylori IgG antibody (DRG KIT, USA).

Molecular part of this study: DNA extraction:
Total human genomic DNA was isolated according to the Promega kit (USA).

Extraction of Genomic DNA from Whole Blood.

Human genomic DNA was

extracted from whole blood specimens

using DNA extraction kit (Promega

USA).

Extraction of Genomic DNA from study bacteria:

DNA extraction was performed using the Wizard ${ }^{\circledR}$ SV kit (Promega, Madison, USA). PCR amplification reaction was used according to Milyani (2011).

\section{Pre PCR:}

After DNA quantitationthe next step including pre PCR for see DNA present or no. that use agarose $0.70 \mathrm{~g}$ dissolved in $(10 \mathrm{ml}$ TBEbuffer $+90 \mathrm{ml}$ D.W.) and heating on flame for 5-10 min., until completely melted and leaves to cool at room temperature and placed in the tank for $15-30 \mathrm{~min}$. the gel chamber ends with sticky plastic tapes. When the agarose gel had cooled down and become solid, the comb was removed carefully by gently pulling it straight up with the tray surrounding tapes, AL-Khalifawi Samira M.S., (2010).

After that $4 \mu \mathrm{I}$ Blue Loading Dye was added to $10 \mu \mathrm{I}$ DNA sample mixed both and take $14 \mu \mathrm{I}$ by micropipette in well. The gel with tray was laid into the chamber with $1 \mathrm{x}$ TBE, and assured that the gel was completely covered with TBE, until top surface of the gel submerged with approximately $2 \mathrm{~min}$, and that the wells were at the negative electrode.

The safety cover was placed onto the chamber carefully ensuring that both plugs were secured and connected with power supply, AL-Khalifawi Samira M.S., (2010). Electrophoresis conditionwas set up at 125 volts for 1 hours if use large tanke while if use small tanke Electrophoresis condition was set up at 75 volts for 1 hours. After that the 
power supply was turned off, and disconnected the leads. The gel for DNA fragments were observed by examining the gel under UV light of transilluminator with protective glasses, AL-Khalifawi Samira M.S. (2010).

\section{Polymerase Chain Reaction (PCR):}

All the samples of bacterial culture and blood were examined for DNA extraction which were assayed by PCR amplification process. The specific primers were synthesized from (DNA sorb-B sacace biotechnologies. USA). Which were designed on the basis sequence information of the gene repeated unit that amplifies a highly repeated sequence of $H$. pylori.

PCR reaction kit (DNA sorb-B sacace biotechnologies. USA) consist of from this materials:

1-PCR mix-1 55 ready-to use singledose test tubes.

2-PCR mix -20.6 ml.

3-Positive control c+, $0.1 \mathrm{ml}$.

4-Negative control *, 1,2 ml.

5-DNA-buffer, $0.5 \mathrm{ml}$., contains reagents for 55 tests.

The thermal cycler (ESCO, USA) was used with a thermal profile involving initial denaturation $5 \mathrm{~min}$ at $95 \mathrm{c}$, denaturation 1min.at 95c, annealing $1 \mathrm{~min}$., at $65 \mathrm{c}$, extension $1 \mathrm{~min}$. at $72 \mathrm{c}$, and a final extension step at 72 for $1 \mathrm{~min}$. Prior to the first cycle, the mixture was heated at 95 for 5 min which is sufficient to ensure that the DNA as well as the primers have melted, so both the template DNA and the primers have completely separated and become single strand. Our PCR process consists of a series of thirty cycles. Each cycle consists of three steps: Denaturation: The DNA sample was heated to 95 for $1 \mathrm{~min}$. for each cycle in order to separate the strands ; it breaks apart the hydrogen bonds that connect the two DNA strand. Annealing: After separating the DNA strands, the temperature was lowered, so the primers can attach themselves to the single DNA strands. The temperature of this stage depends on the primers which is usually 5 below their melting temperature, so the temperature used was 65 for $1 \mathrm{~min}$.

A wrong temperature during the annealing step can result in unbinding of the primer to the template DNA at all, or binding at random. The primers are jiggling around. They are caused by the Brownian motion, and short bonds which are constantly formed between the single stranded primer and the single stranded template. Extension: Finally, the sample heated at 72 for $1 \mathrm{~min}$. The DNA polymerase starts copying the DNA strands. It starts at the annealed primer and works its way long the DNA strand. The Taq polymerase elongates optimally at a temperature of 72 , and the time for this step depends both on the DNA polymerase itself and on the length of the DNA fragment to be amplified.

A final elongation step was used after the last cycle to ensure that anyremaining single stranded DNA was completely copied. The PCR products were identified by their size using agarosegel electrophoresis. The size of the PCR products was determined by comparing them with a DNA ladder (Promega, 1000 bp DNA pench top, USA) which contains DNA fragments of known size.

\section{RESULTS}

A total of 85 specimens were collected from patient with dyspepsia. Of these, 65 were non- ulcer dyspepsia (NUD) and the other 20 samples were patient, infected with $H$. pylori. Blood and biopsy specimen obtained from patient to detected of $H$. pylori. The diagnosis of this disease was based on the result of urease, culture, ELISA and PCR. Urease test (UT) was used to diagnose of $H$. pyloriand conducted immediately after obtaining the biopsy from the patient. The positive result appear pink colorin the presence of $H$. pylori. The time taken for the positive 
reaction was one minute to 1 hour. Out of7 (8.23\%) patients with GU, $5(5.91 \%)$ patients with PU, $10(11.75 \%)$ patients

with DU and 28 (32.94\%) patients with NUD were positiveby urease test (UT) (Table 1).

Table 1: The result of urease positive and negative test in patients with gastric cancer (GU), peptic ulcer disease (PUD), duodenal ulcer disease (DU) and non-ulcer dyspepsia (NUD).

\begin{tabular}{|c|c|c|c|}
\hline Type of specimen & $\begin{array}{c}\text { No. of } \\
\text { specimen }\end{array}$ & Urease test positive(+ve) & Urease test negative(-ve) \\
\hline Gastric ulcer & 7 & $7(8.23 \%)$ & $0(0.0 \%)$ \\
\hline Peptic ulcer & 5 & $5(5.91 \%)$ & $0(0.0 \%)$ \\
\hline Duodenal ulcer & 10 & $10(11.75 \%)$ & $0(0.0 \%)$ \\
\hline Non-ulcer dyspepsia & 63 & $28(32.94 \%)$ & $35(41.17 \%)$ \\
\hline
\end{tabular}

In many cases color change started within 30 minutes but in other cases the color change within 1 hour or more.

The culture of all specimens on Brucellachocolate agar was detected only $10(11.75 \%)$ of the positive cases divided according to patient status.A total
$3(3.52 \%)$ had patients with GU, 4 (4.71\%) patients with PU and $3(3.52 \%)$ patients with DU were positiveby culture while no one of NUD patients were positive by culture (see Table 2 and Fig. 2).

Table 2: The result of $H$. pylori positive and negative culture depend on patient status.

\begin{tabular}{|c|c|c|c|}
\hline Type of specimen & $\begin{array}{c}\text { No. of } \\
\text { specimen }\end{array}$ & $\begin{array}{c}\text { Culture positive cases } \\
\text { No. }(\%)\end{array}$ & $\begin{array}{c}\text { Culture negative } \\
\text { cases No. }(\%)\end{array}$ \\
\hline Gastric ulcer & 7 & $3(3.52 \%)$ & $4(4.71 \%)$ \\
\hline Peptic ulcer & 5 & $4(4.71 \%)$ & $1(1.2 \%)$ \\
\hline Duodenal ulcer & 10 & $3(3.52 \%)$ & $7(8.23 \%)$ \\
\hline Non-ulcer dyspepsia & 63 & $0(0.0 \%)$ & $63(74.11)$ \\
\hline
\end{tabular}

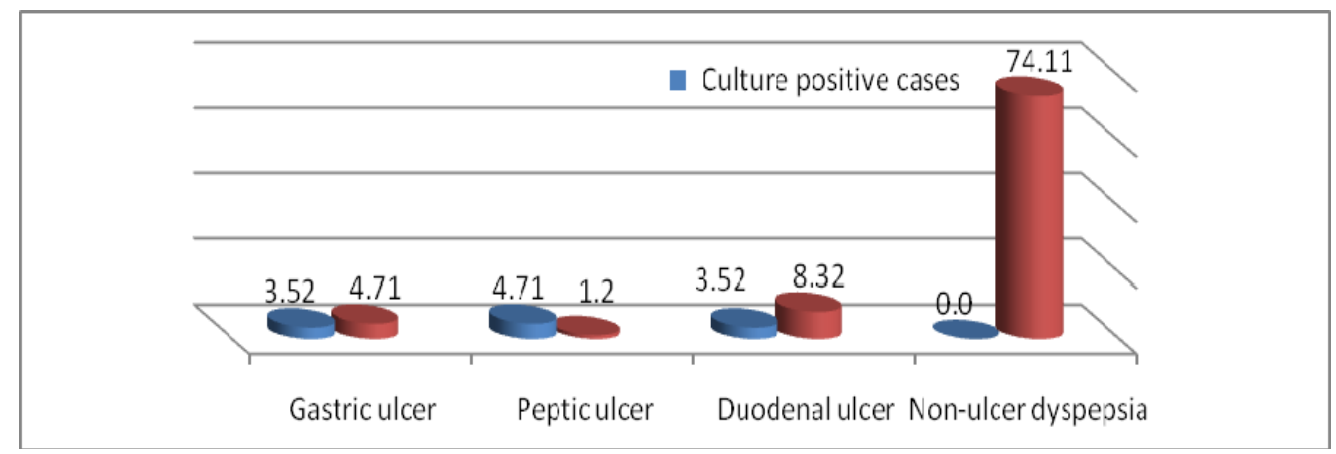

Fig. 2: Distribution of $H$. pylori positive and negative culture depend on patient status.

Despite meticulous care in the whole steps of culturing including careful media preparation, transport, and incubation atmosphere and identification steps. Colonies of $H$. pylori were appearance water droplets, small, convex and translucent on Brucella chocolate agar after 7 days of incubation. The study isolates were identified by urease test and microscopical appearance by using modified Gram's staining. The statistical analyses showed no significance differences between culture and PCR considering $\mathrm{P}$ value was more than 0.05 .

ELISA test use for detection $H$. pylori IgG level in patient with $H$. pylori infection. Out of 85 cases of dyspepsia, Significant IgG titers $(>1.915 \mathrm{u} / \mathrm{mL})$ were detected in $18(21.2 \%)$ serum samples.All cases which were positive by ELISA test had, significantlyurease test positive. There was no difference in antibody levels between men and women or smokers and nonsmokers or among 
different blood groups. The positive result when compare with control positive and control negative that refers to truly positive or have a disease while negative result that refers to truly negative or do not have disease. The statistical analyses showed the $H$. pylori positive patients showed significantly higher titers of anti $H$. pylori $\operatorname{IgG}(1.840$ \pm 0.421 ) in serum samples than $H$. pylori negative subjects $(0.503 \pm 0.142)$ $(p<0.001)$. According to our result, there was high significance difference when the comparison of two groups of patients one of them is serologically positive for IgG and the other was negative.

In PCR testa total of 85 samples were collected from infected individuals, were investigated for $H$. pylori infectionsby both PCR of DNA obtained from growth culture and PCR of DNA obtained directly from human blood. For culture used biopsy was taken by endoscopy from antrum and corpus region in selective media for $H$. pylori growth. The PCR used for detection 16srRNA gene that specific for $H$. pylorinot in other strains. The 16srRNA gene reacted with human tissuesamples therefore ourextracted DNA from blood and tissue culture and amplificatedby PCR for detect 16srRNA.Extracted DNA from bloodindicates that $H$. pyloriDNA might circulate in peripheral blood. The selection of samples which submitted to PCR technique was depend on results of urease and ELISA tests. All positive urease and ELISA samples were used in PCR. PCR showed $20(100 \%)$ of cases positive result fromhuman bloodwhile 6 $(60 \%)$ of cases were positive result of PCR from bacterial colonies (Table 3).

Table 3: PCR result for $H$ pylori genome extracted from blood and bacteria

\begin{tabular}{|c|c|c|c|c|}
\hline No. of specimen & $\begin{array}{c}\text { PCR positive for } \\
\text { blood samples }\end{array}$ & $\begin{array}{c}\text { PCR negative for } \\
\text { blood samples }\end{array}$ & $\begin{array}{c}\text { PCR positive for } \\
\text { bacteria }\end{array}$ & $\begin{array}{c}\text { PCR negative for } \\
\text { bacteria }\end{array}$ \\
\hline 85 & $20(100 \%)$ & $65(0 \%)$ & $6(60 \%)$ & $4(40 \%)$ \\
\hline
\end{tabular}

The statistical analyses showed high significant difference of PCR results between human blood and bacterial colonies PCR positive $(\mathrm{P}<0.001)$. Out of 20 samples of $H$. pylori DNA extracted from blood of patients infected with $H$. pylori (as indicated by urease and ELISA tests), all these DNA samples (100\%) revealed large DNA diagnostic band with $520 \mathrm{bp}$ as showing in the following figures stained with ethidium bromide (Figure 7a).

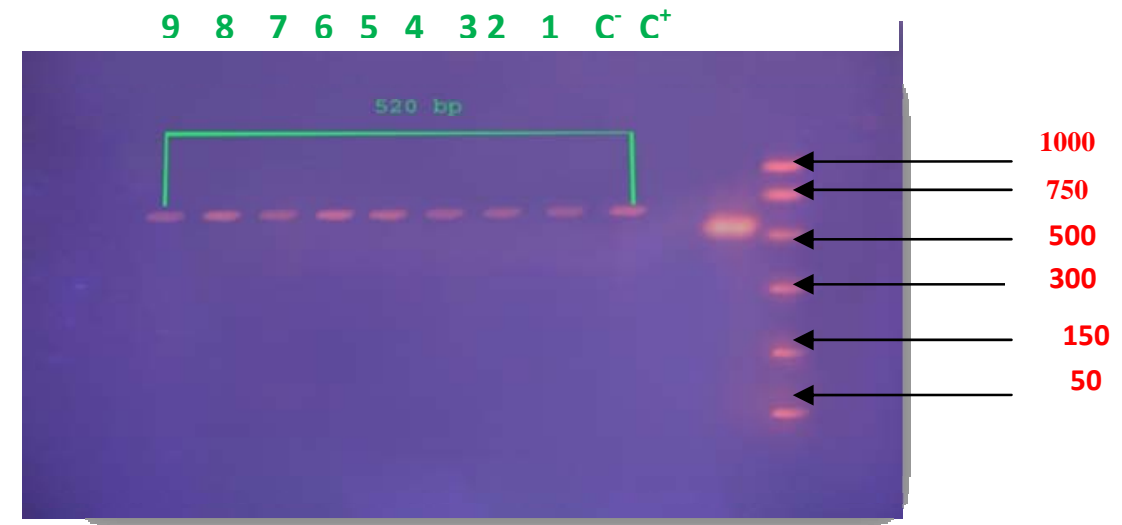

Fig. 1: PCR-blood positive samples bands $(1,2,3,4,5,6,7,8,9)$ by using $2 \%$ agarose gel, ethidium bromide, $\mathrm{C}+$ (control positive), $\mathrm{C}$ - (control negative), Bench top marker (50-1000 pb). 


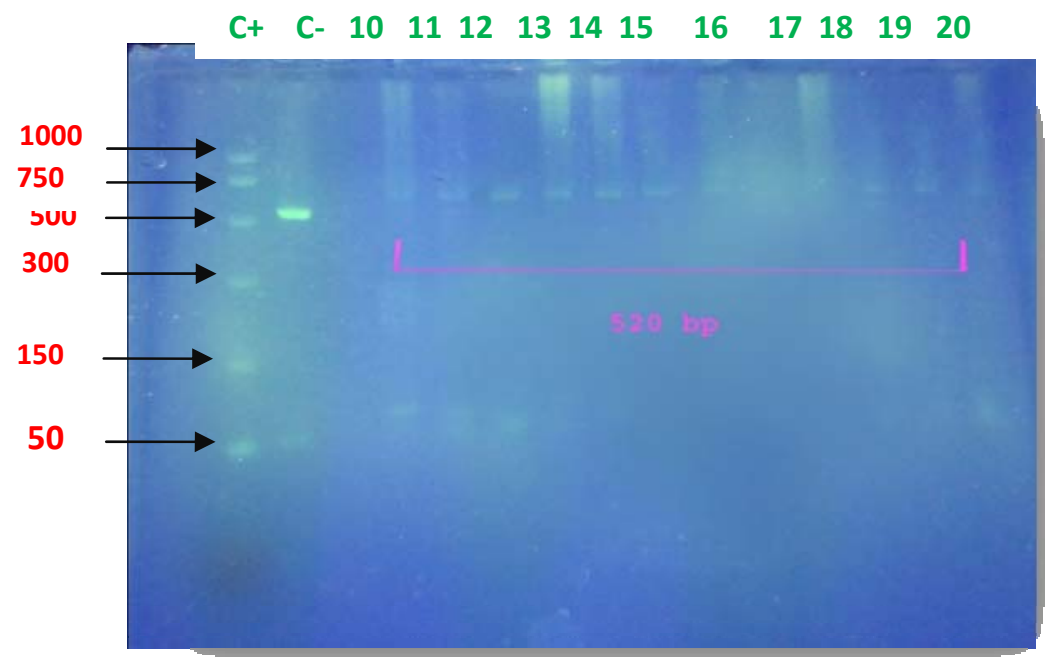

Fig. 2: Bacterial genome extracted from blood bands $(10,11,12,13,14,15,16,17,18,19,20)$ by using agarose $2 \%$, Red safe Nucleic acid staining solution. $\mathrm{C}+($ control positive), C-(control negative) and Bench top marker (50-1000 base per).

A total of $10(11.7 \%)$ cases which were positive for culture the results of descriptive agarose gel electrophoresis revealed that large DNA diagnostic bands were detected in $6(60 \%)$ of them with $520 \mathrm{bp}$ from bacterial genome extracted from bacterial colonies while $4(40 \%)$ were negative (see the following Fig. 7b).

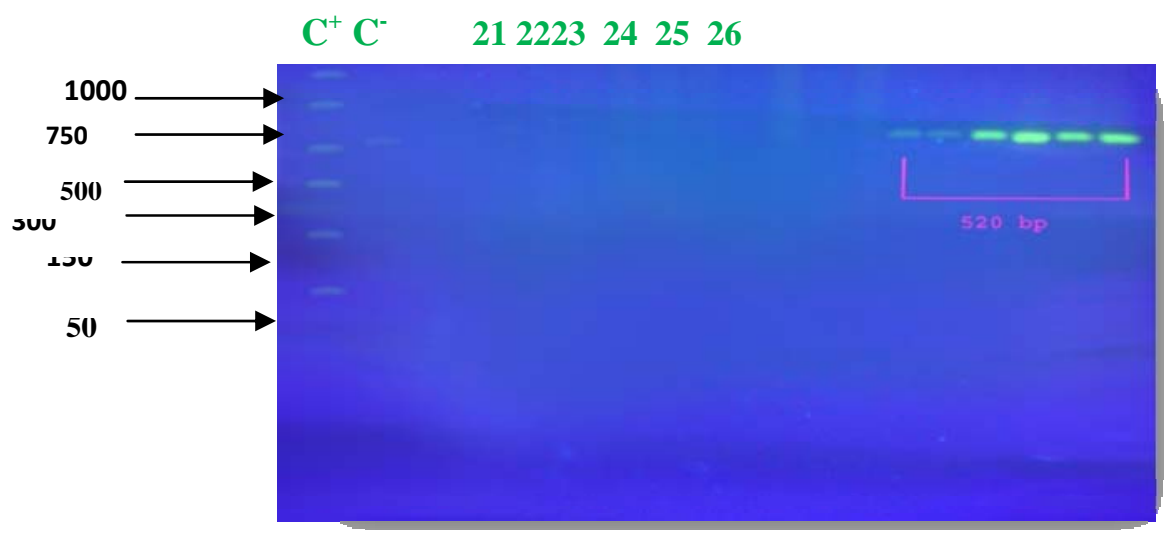

Fig. 3: Bacterial genomebands extracted from bacterial colonies $(1,2,3,4,5,6)$ by using $2 \%$ agarose gel, Red safe Nucleic acid staining solution. C+(control positive), C-(control negative), Bench top marker (50-1000bp).

\section{DISCUSSION}

Our study was laid down to detect H.pylori infection depending on conventional techniques like urease test and culture. Further, to detect the role of 16srRNA gene in the detection of $H$. pylori from blood and bacterial culture.Several approaches can be used to diagnose $H$. pylori infection. The selection of the appropriate tests depends on the clinical setting. $H$. pylori infection can be diagnosed by tests requiring upper gastrointestinal endoscopy for the retrieval of a gastric biopsy specimen Abdelfattah M. et al.,(2004).

Regarding urease test the majority of positive cases showed color changes within the several minutes to one hour of incubation indicating the production of large amounts of urease enzyme by the bacteria. Our study result was disagree with those observed by Tiwarisk, A A Khan, et al., (2005). This may be due to the biopsy specimen were taken from 
non-targeted area, thus negative result appears. Alsothedensity of colony may be few in biopsy that lead to late appearance of urease positive. In some cases of NUD false positive results of urease test appear after 24 hours may be caused by recent ingestion of antibiotic agents, bismuth compounds, proton pump inhibitors or by bilerefluxandmay be contaminated with other ureasepositive bacteria i.e., klebsiella and proteus. Our study in agreement with Kargar and co-workers, et al., (2010).

With regard to culture technique out of 85 cases, $10(11.75 \%)$ of them were culture positive while other were negative. Our studyis inagreement with Abdullah Essam M, (2002), while disagreement with those observed by Luigina Cellinil et al., (2010). Thismay be patchy distribution in gastric mucosa, fastidious nature, mucosal atrophy, intestinal metaplasia (in stomach), administration of antibiotics.In additionto that endoscopy sterilization in large amounts may affect on bacteria and finally might influence the results of culture. False negative culture result may be due to the $H$. pylori is slow growing and it is possible that some $H$. pylori strains will not form colonies on some currently available media or $H$. pylori cells in the coccoid stage cannot be cultured and can be detected only by culture-independent strategies, Shahamat, M. et al., (1993).

Regard with ELISA technique, fast, easy, and relatively in expensivemeans of identifying patients who have been infected with the organism. However, this method is not a useful means of confirming eradication of $H$. pylori. ELISA techniquecannot distinguish between pastand present infections as antibody titers declinevery slowly even after successful $H$. pylori eradication that lead to false positive result, Rasool Estakhri, et al., (2008),

In low-prevalence populations, serologic tests should be a second-line methodology because of low positive predictive value and a tendency toward falsepositive results. Our studyin agreement with Abdullah Essam $M$ (2002), while disagreement with Arora, U. et al.,(2003), because false-negative results that may be occur in patients with acute phase of infection ,the concentration of anti $H$. pylori $\operatorname{IgG}$ is not sufficient to appear more than ELISA cutoff.

More importantly, no one of these techniquesaccurately quantifies the number of $H$. pylori present in test samples. BecauseH.pylori is a fastidious slow-growing bacterium, it requires 4 to 5 days to growin rich media and it requires specific culture conditions. The urease assay is no sensitiveand may not be specific in the presence of other urease-positive bacteria like klebsiella and proteus Ashok Kumar and Imran Khan. (2010). Further serology may not differentiate active frompast infection and cannot be used to indicate the clearance of $H$. pylori from thestomach because antibodies may stay at the same level even after eradication of thebacteria. All of these causes lead to use advanced technique polymerase chain reaction (PCR).

It is well know that PCR is a powerful method known for its high sensitivity, can detect low numbers of $H$. pylori and has been used to follow up eradication. However, by the emergence of the new technology of polymerase chain reaction (PCR), researchers started to detect $H$. pylori using PCR, $16 \mathrm{~S} \mathrm{r}$ RNA gene, Clayton, L. C. et al., (1992) and Twing, KI. et al.,(2011).

Our study was investigated the use of newer techniques of Polymerase Chain Reaction (PCR) to identify $H$. pylori in samples obtained from bacterial colonies and from human blood. Choosing of this project for the present research might be due to the importance of PCR for detection pathogenic bacteria, such PCR amplification uses primers 
designed to target putative transcription regulator gene of this bacteria. In our study4 (40\%) were negative result of PCR from bacterial colonies, this result due to presence small bacterial colonies, in specimen that took from bacterial culture that lead to low DNA concentration and DNA yield that cause disappear DNA bands. Our study in agreement with Bindayna et al. (2006), while disagreement with Huanget et al., (2006). The study concluded thaturease test was useful as preliminary screening test and important in give indicate for $H$. pylori present, further. The role of culture was very important test in the detection of $H$. pylori in clinical samples. The study have been successed in the isolation of this bacteria, furthermore of the immunologically bases serological test, ELISA technique was sensitive test and help in give an indicator for the presence of $H$. pylori in association with the other tests, also PCR PCR was sensitive and specific test of diagnosis that indicates the presence of $H$. pylori DNA in clinical samples, and it was recommended as an outstanding sensitive $\&$ specific diagnostic tool for indicative of the presence of $H$. pylori DNA in clinical samples of individuals by amplifying highly repeated DNA sequence termed Putative Transcriptional Regulator Gene at 520 bp in the genome of H. pylori.

\section{REFERENCES}

Abdelfattah M. Attallah, Hisham Ismail, Gellan G. Ibrahim, Mohamed AbdelRaouf, Ahmed M. El-Waseef and Mohamed Abdel-Wahab., (2004). Use of a Novel Enzyme Immunoassay Based on Detection of Circulating Antigen in Serum for Diagnosis of Helicobacter pylori Infection p. 1

Abdullah, Essam M. (2002). Comparative study of different serological and bacteriological methods in detection of $\mathrm{H}$. pylori. $\mathrm{P}$ (79).

Al-Khalifawi Samira M.S. (2010). Microbiological Study on Group A Beta-Hemolytic Streptococci Isolated from patients with Tonsillitis in Ramadi City.

Arora, U.; Aggarwal, A. and Singh, K. (2003). Comparative evaluation of conventional methods and ELISA based IgG antibodies detection for diagnosis of helicobacter pylori infection in cases of dyspepsia, p.3-4

Ashok Kumar and Imran Khan. (2010). Detection of Helicobacter pylori in Gastroduodenal Diseases by Real Time PCR; 170-178.

Aydin F.; Kaklikkaya N.; Ozgur O.; Cubukcu K.; Kilic AO.; To sun I. and Erturk M. (2004). Distribution of vacA alleles and cagA status of Helicobacter pylori in peptic ulcer disease and non-ulcer dyspepsia. Clin Microbiol Infect, 10:1102 - 1104.

Bindayna KM.; WA Al Baker and Botta, GA. (2006). Detection of Helicobacter pylori cagagene in gastric biopsies, clinical isolates and faeces. July20 06India $\mathrm{n}$ Journal of Medical Microbiology, 24 (3):195200.

Chong SK, Lou Q, Fitzgerald JF, Lee CH.. (1996). Evaluation of $16 \mathrm{SR}$ RNA gene PCR with primers Hp1 and $\mathrm{Hp} 2$ for detection of Helicobacter pylori J Clin Microbiol; 34:2728-30.

Clayton L C, Kleanthous H, Coates J P, Morgan D D and Tabaqchali S. (1992). Sensitive detection of Helicobacter pylori by using polymerase chain reaction. J Clin Microbial. January; 30(1): 192-200.

Graham DY. (1991). Helicobacter pylori its epidemiology and its role in duodenal ulcer disease. J Gastro enterol Hepatol; 6:105-13.

Gramley WA, Asghar A, Frierson HF Jr, Powell SM. (1999). Detection of Helicobacter pylori DNA in fecal 
samples from infected individuals. J Clin Microbiol; 37:2236-40.

Ho SA, Hoyle JA, Lewis FA, Secker AD and Cross D. (1991). Direct polymerase chain reaction test for detection of Helicobacter pylori in humans and animals. J ClinMicrobiol 29: 2543-2549.

Hoshina S, Kahn SM, Jiang W, Green PH, Neu HC, Chin N. (1990). Direct detection and amplification of Helicobacter pylori ribosomal 16S gene segments from gastric endoscopic biopsies. Diagn Microbial Infect Dis; 13:473-9.

HUANG, Y., FAN, X.-G., TANG, Z.-S., LIU, L., TIAN, X.-F. and LI, N. (2006). Detection of Helicobacter pylori DNA in peripheral blood from patients with peptic ulcer or gastritis. APMIS, 114: 851-856. doi: 10.1111/j.1600-0463.

Kargar M., Baghernejad M., Doosti A. (2010). Role of NADPH insensitive nitroreductase gene to metronidazole resistance of Helicobacter pylori strains.18 (2) $137-140$

Luigina Cellinil, Rossella Grande, Luciano Artese, Leonardo Marzio2. (2010). Detection of Helicobacter pylori in saliva and esophagus; 33, 351-357.

Marshall BJ and Warren JR., (1984). Unidentified curved bacilli in the stomach of patients with gastritis and peptic ulceration. Lancet; 1: 13111315 .

Morgan C, Jenkins GJ, Ashton T, Griffiths AP, Baxter JN, Parry EM, Parry JM. (2003). Detection of p53 mutations in precancerous gastric tissue. Br J Cancer; 89: 1314 -1319.

Rasool Estakhri, Homayoon Dolatkhah, Ardavan Ghazanchaei, Behrooz Pourasgari and Manuchehr Nourazarian. (2008), Saliva or serum, which is better for the diagnosis of gastric Helicobacter pylori infection., 3(3):121-125.
Shahamat, M., U. Mai, C. Paszko-Kolva, M. Kessel, and R. R. Colwell. (1993). Use of autoradiography to assess viability of Helicobacter pylori in water. Appl. Environ. Microbiol. 59:1231-1235.

Tiwarisk, A A Khan, K S Ahmed, I Ahmed, F Kauser, M A Hussain, S M Ali, A Alvi, A Habeeb, Z Abid, N Ahmed, C M Habibullah. (2005).Rapid diagnosis of Helicobacter pylori infection in dyspeptic patients using salivary secretion: a non-invasive approach. Original Article Singapore Med J 46(5): 224

Twing KI, Kirchman DL and Campbell B. J., (2011). Temporal study of Helicobacter pylori presence incoastal freshwater, estuary and marine waters. Water Research 45:1897- 1905.

Yoshida H, Hirota K, Shiratori Y, Nihei T, Amano S, Yoshida A. (1998). Use of a gastric juice-based PCR assay to detect Helicobacterpylori infection in culture-negative patients. J Clin Microbiol; 36:317-20.

Zagari RM, Bazzoli F, Pozzato P, Fossi S, De Luca L, Nicolini G. (1999). Review article: non-invasive methods for the diagnosis ofHelicobacter pylori infection. Ital J Gastroenterol Hepatol, 31:408-15. 